\title{
Involvement of Suboccipital Muscles in Plasmacytoma of Occipital Bone
}

\section{Envolvimento suboccipital de músculos em plasmocitoma de osso occipital}

\author{
Aravinth Kumar Ashok ${ }^{1}$ Mahendran Jolarpettai Venugopal ${ }^{1}$ Jothikumar Sethuraman ${ }^{1}$ \\ Shankar Ranganathan ${ }^{1}$ \\ ${ }^{1}$ Institute of Neurosurgery, Madras Medical College, Chennai, Tamil \\ Nadu, India \\ Address for correspondence Mahendran J. Venugopal, PhD, Institute \\ of Neurosurgery, Madras Medical College, Chennai, Tamil Nadu, India \\ (e-mail: mahendranvenugopal@gmail.com).
} Arq Bras Neurocir 2016;35:160-168.

\begin{abstract}
Keywords

- plasmacytoma

- solitary

- occipital bone

- suboccipital muscle involvement

- progression to multiple myeloma

- follow-up protocol
\end{abstract}

\section{Resumo}

Introduction Suboccipital muscle involvement in a plasmacytoma of occipital bone is a rare clinical event. It leads to a dilemma of categorizing it into either Solitary plasmacytoma or extra medullary plasmacytoma. A working protocol is necessary to follow up these patients to detect their progression into multiple myeloma.

Clinical Presentation A 38-year-old man presented with a progressively increasing hard swelling in the occipital region of five years duration. Brain CT revealed an osteolytic SOL over the torcula extending up to the foramen magnum. Brain MRI revealed an extraxial lesion. Brain MRV revealed no involvement of the torcula. Skeletal survey for metastasis was normal. After evaluation, we performed a surgical excision of the lesion. Intraoperatively, the tumor had invaded the suboccipital muscles and parietal bone and was adherent to the dura, without any intracranial extension. Histopathology reported Plasmacytoma. Immunohistochemical analysis was positive for $\mathrm{CD}-138$. Bone marrow biopsy was negative for plasma cells. Bence Jones protein was absent and $\mathrm{M}$ protein absent in serum electrophoresis. USG abdomen normal. The patient underwent radiotherapy and is under continuous follow-up.

Conclusion Plasmacytoma of occipital bone with suboccipital muscles involvement is categorized as Solitary Plasmacytoma of the bone. This provides convenience in diagnosis, management, and follow-up. We report on this case for its rarity in presentation. The protocol followed in our institute, based on our experience with such tumors, will aid in early identification of the progression of solitary plasmacytoma of bone into multiple myeloma and will augment prompt management.

Justificativa e Importância O envolvimento suboccipital de músculos em um plasmocitoma do osso occipital é um evento clínico raro. Isso leva a um dilema de categorizá-lo em qualquer plasmocitoma solitário ou plasmocitoma extramedular. Um protocolo de trabalho foi formulado para acompanhar esses pacientes para detectar a sua progressão para mieloma múltiplo. received

December 14, 2015

accepted

February 25, 2016

published online

April 22, 2016
DOI http://dx.doi.org/

10.1055/s-0036-1583178. ISSN 0103-5355.
Copyright $(2016$ by Thieme Publicações License terms

Ltda, Rio de Janeiro, Brazil
(1) $\Theta \circledast$ 


\author{
Palavras-chave \\ - plasmocitoma \\ - solitária \\ - osso occipital \\ - envolvimento do \\ músculo suboccipital \\ - múltiplo mieloma \\ - protocolo de \\ acompanhamento
}

Apresentação Clínica Um senhor de 38 anos apresentou um aumento progressivo duro inchaço na região occipital uma duração de cinco anos. CT-cérebro revelou uma lesão osteolítica sobre o tórcula estendendo-se até o forame magno. MRI revelou uma lesão extra-axial sem violação dural. MRV excluiu a participação do tórcula. O exame do esqueleto para a metástase foi negativo. Após a avaliação, a excisão da lesão foi feita. $\mathrm{O}$ tumor invadiu de forma intra operatória os músculos suboccipital, osso parietal e encontrado para ser aderente ao dura, sem qualquer extensão cranial intra. $O$ exame histopatológico foi relatado como Plasmocitoma. A análise imuno-histoquímica foi positiva para CD-138. A biópsia de medula óssea foi negativa para células plasmáticas. A proteína de Bence Jones estava ausente. $\mathrm{H}$ proteína estava ausente em eletroforese soro. USG abdome era normal. A radioterapia foi dada. O paciente foi colocado sob contínuo acompanhamento.

Conclusão Plasmocitoma do osso occipital com o envolvimento do músculo suboccipital é classificado como Solitary plasmocitoma do osso. Isso proporciona comodidade no diagnóstico, tratamento e acompanhamento. Este caso está sendo relatado pela sua rara apresentação. O protocolo desenvolvido por nós e rotineiramente seguidos em nosso instituto, vai ajudar na detecção precoce da progressão e transformação de plasmocitoma solitário do osso para mieloma múltiplo e irá aumentar a gestão rápida.

\section{Introduction}

Plasmacytoma of occipital bone with suboccipital muscles involvement is a rare clinical presentation. Such an entity could not be found in existing literature. ${ }^{1-5}$ Plasmacytoma of the head and neck is classified into two entities, namely, solitary plasmacytoma of bone and extramedullary plasmacytoma. ${ }^{1,2}$ The case in discussion does not fit the diagnostic criteria of either one. Suboccipital muscles involvement has rarely been encountered in cases reported to date. ${ }^{3-6}$ Hence, there is a dilemma in categorizing this case for the purpose of diagnosis and management. Moreover, such lesions have a high propensity to progress into multiple myeloma. ${ }^{1,7,8} \mathrm{We}$ feel a longstanding need for a follow-up protocol to detect progression into multiple myeloma, which will help avoid any delays in further management. We report on this rare case for its unique presentation and to define the follow-up protocol designed and being followed at our institute.

\section{Clinical Presentation}

A 38-year-old gentleman came to our institute with complaints of progressive swelling in the occipital region of five years duration, headache of one year duration, and pain over the swelling of a year's duration. The patient noticed a small swelling in the occipital region five years prior that was insidious in onset and grew progressively. The headache was mild, diffuse, on-and-off, more prevalent in the occipital region, and was not associated with symptoms of increased intra cranial pressure. Pain over the swelling was mild, onand-off, and the swelling was not associated with trauma. There was no history of visual disturbance ( - Table 1 ) nor did the patient have any neurological deficit. Past medical history was not contributory to the current illness. There was no history of any radiation exposure. The patient was addicted to alcohol but had abstained from consuming alcohol for the past year. He was not a known smoker and was an agricultural laborer by occupation. History of any prolonged exposure to harmful chemicals was absent.

Upon examination, we saw a $10 \times 10 \times 6 \mathrm{~cm}$ swelling in the occipital region ( - Fig. $\mathbf{1}$ ). The consistency was variable with hard areas near the base and soft with firm areas near the apex. The skin over the swelling was not pulsatile. Serum calcium levels were normal.

\section{Brain Computed Tomography (CT)}

We found an $8 \times 8 \times 6 \mathrm{~cm}$ lytic lesion in the right occipital region extending to the left side. The lesion was extra-axial and was not infiltrating into the brain parenchyma. There was involvement of surrounding soft tissue. Mass effect over the cerebellum was present. We observed no evidence of hydrocephalus (-Figs. 2 and $\mathbf{3}$ ).

\section{Magnetic Resonance Imaging (MRI)}

We observed an $8.7 \times 8 \times 5.6 \mathrm{~cm}$ moderately defined lesion in the right occipital skull bone. The lesion was hyperintense in both $\mathrm{T} 1$ and T2 images. Extension into pericranial soft tissue and

Table 1 Vision

\begin{tabular}{|l|l|l|}
\hline & Right & Left \\
\hline Visual acuity & $6 / 6$ & $6 / 6$ \\
\hline Visual field & Normal & Normal \\
\hline Color vision & Normal & Normal \\
\hline Fundus & Normal & Normal \\
\hline
\end{tabular}




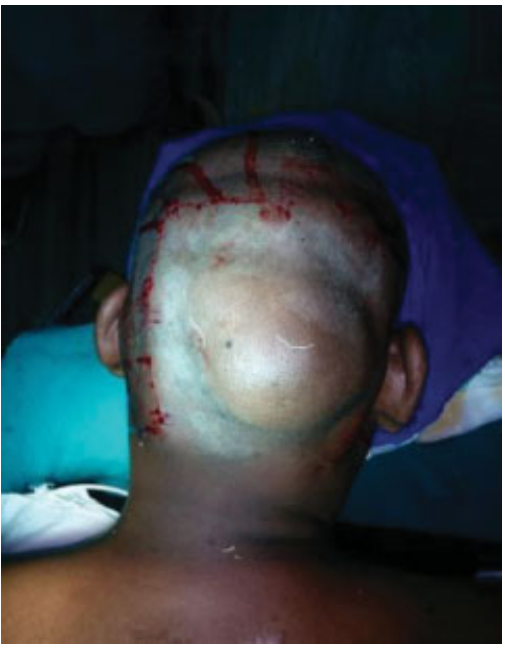

Fig. 1 Clinical preoperative photo of the tumor mass in the occipital region. extradural destruction of skull bone were present. We also observed mass effect with compression of right cerebellum. There was no intraparenchymal extension observed. Intense contrast enhancement was present. Both transverse sinus and sigmoid sinus were normal. We saw no evidence of cerebral venous thrombosis ( - Figs. 4-7).

\section{Surgical Procedure}

With the patient under general anesthesia and in the prone position, we made an inverted U-shaped incision based on both the Transverse Sinuses. We raised the skin flap and identified the tumor mass infiltrating into the occipital bone. We also identified firm areas in the periphery and soft areas in the apex (-Fig. 8). Tumor mass was adherent to the dura, which we carefully separated and cauterized. We found extension of lesion to the parietal bone and suboccipital muscle. Parietal bone was nibbled and

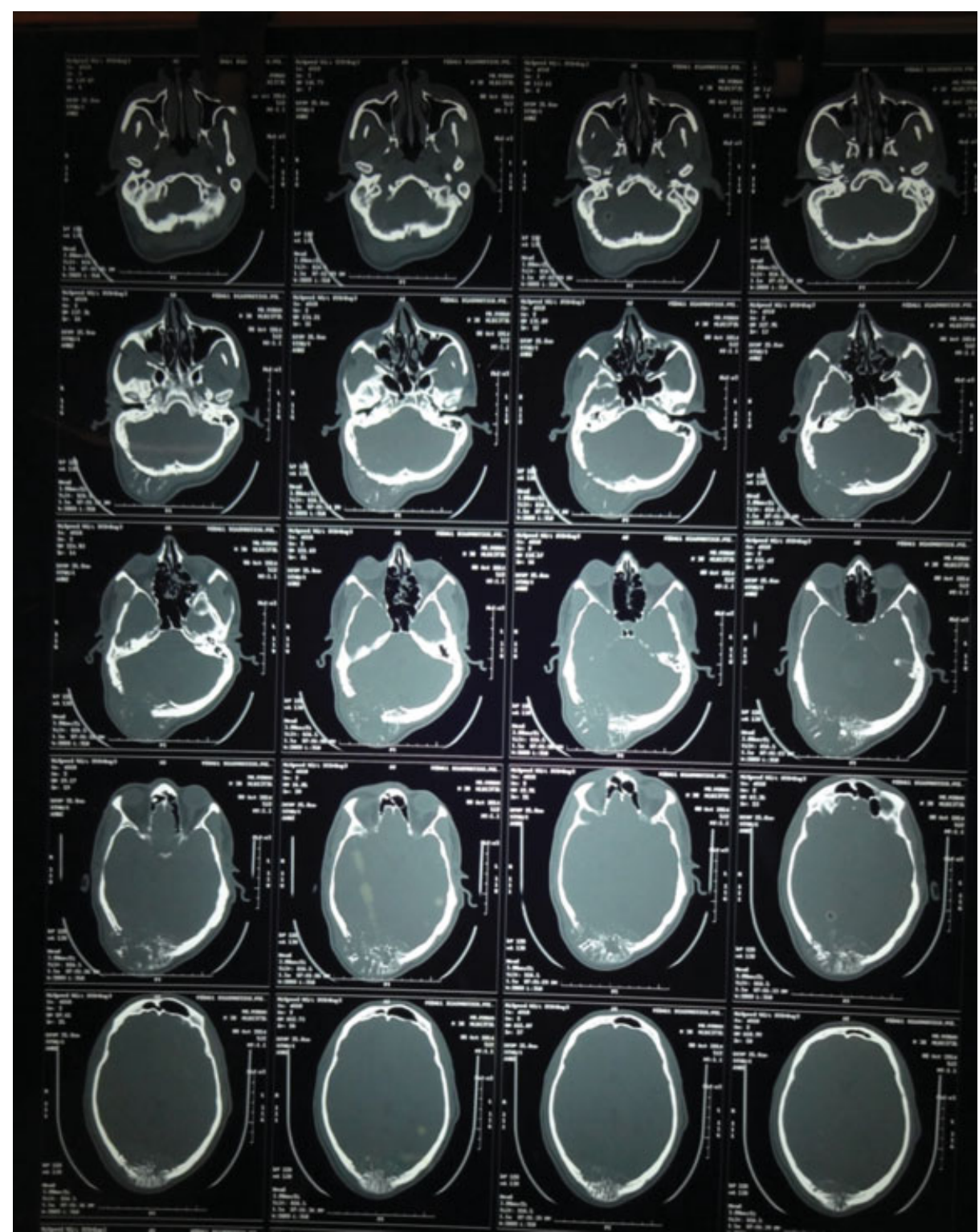

Fig. 2 Computed tomogram picture of the Bone Window. 


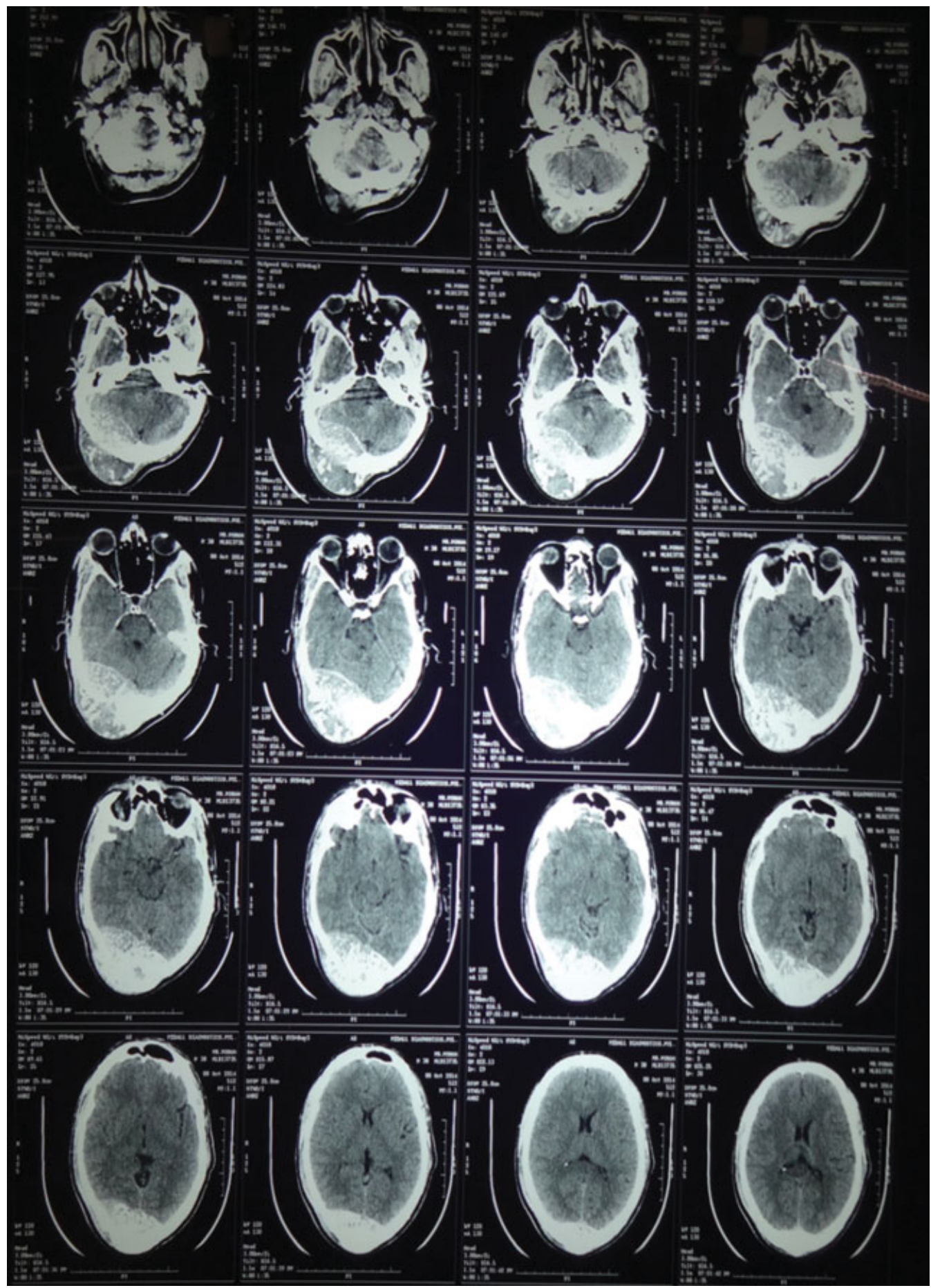

Fig. 3 Computed tomogram picture of the Brain Parenchyma.

suboccipital muscles infiltration was excised. We achieved total excision of the lesion. After confirming hemostasis, the skin was closed in layers and dressing was applied (-Fig. 9). We sent the specimens (bone, suboccipital muscles, and tumor mass) for HPE (histo-pathological examination) (-Figs. 10-12).

\section{Post-Operative Status}

Post-operative period was uneventful. The wound remained healthy. The patient underwent suture removal on the seventh post-operative day. Post-operative brain CT showed complete excision of the lesion (-Fig. 13). 


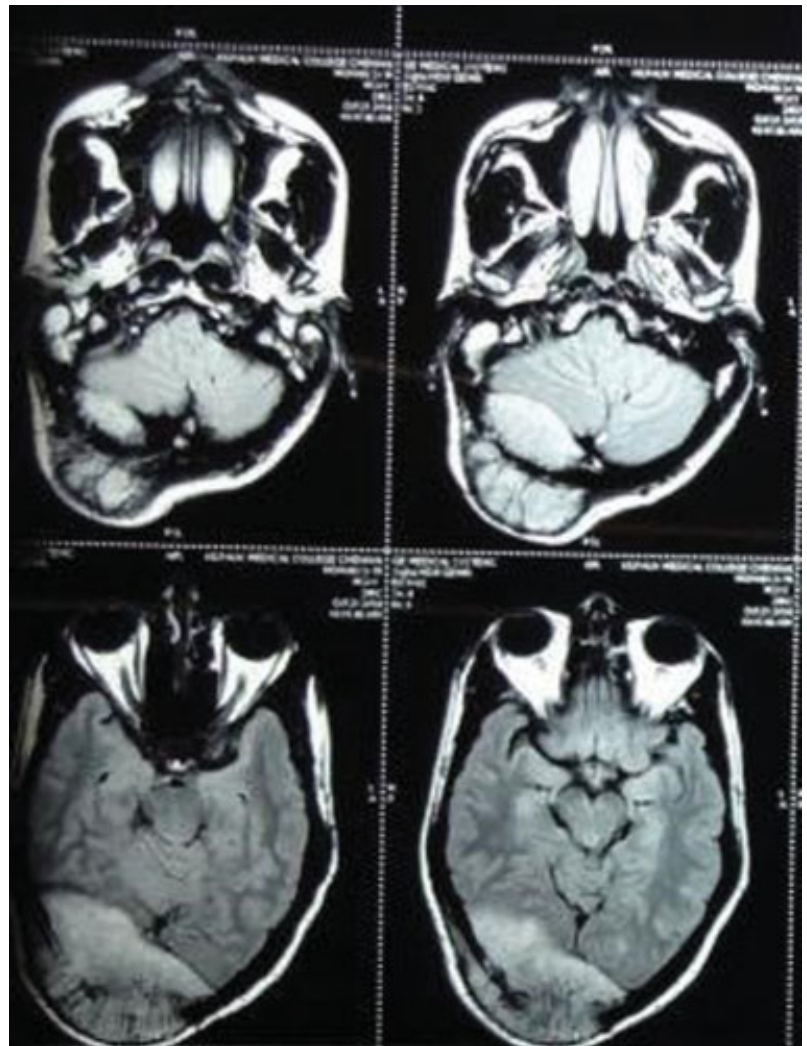

Fig. 4 T1-weighted magnetic resonance Image of the brain.

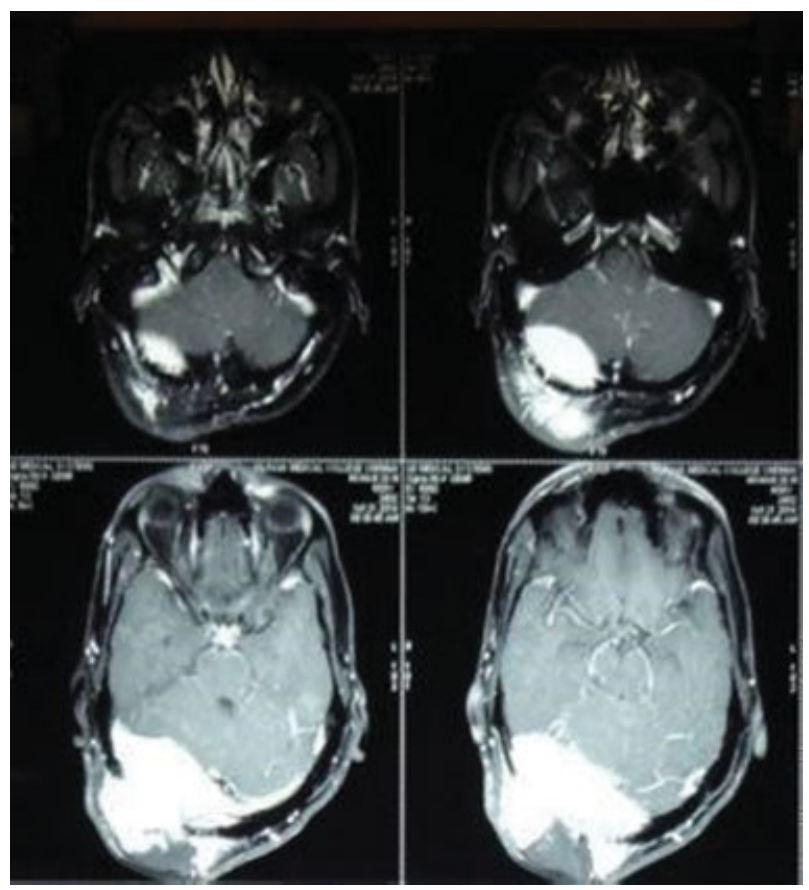

Fig. 6 Contrast magnetic resonance Image of the brain.

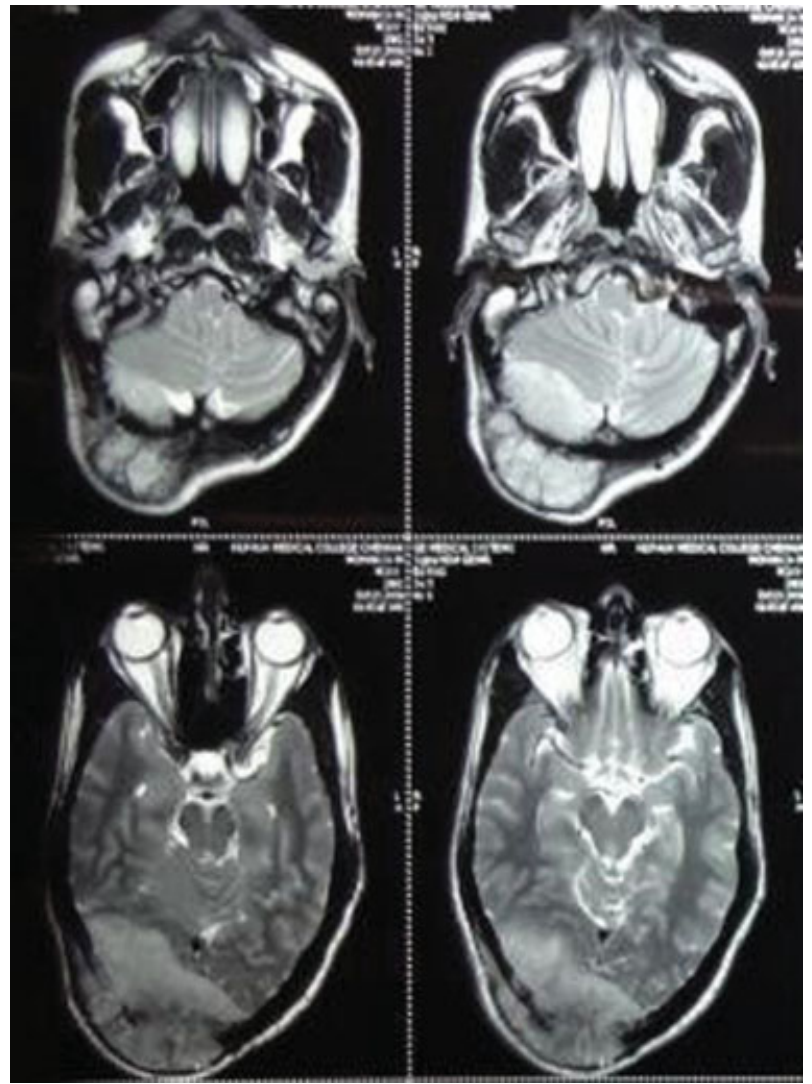

Fig. 5 T2-weighted magnetic resonance Image of the brain.

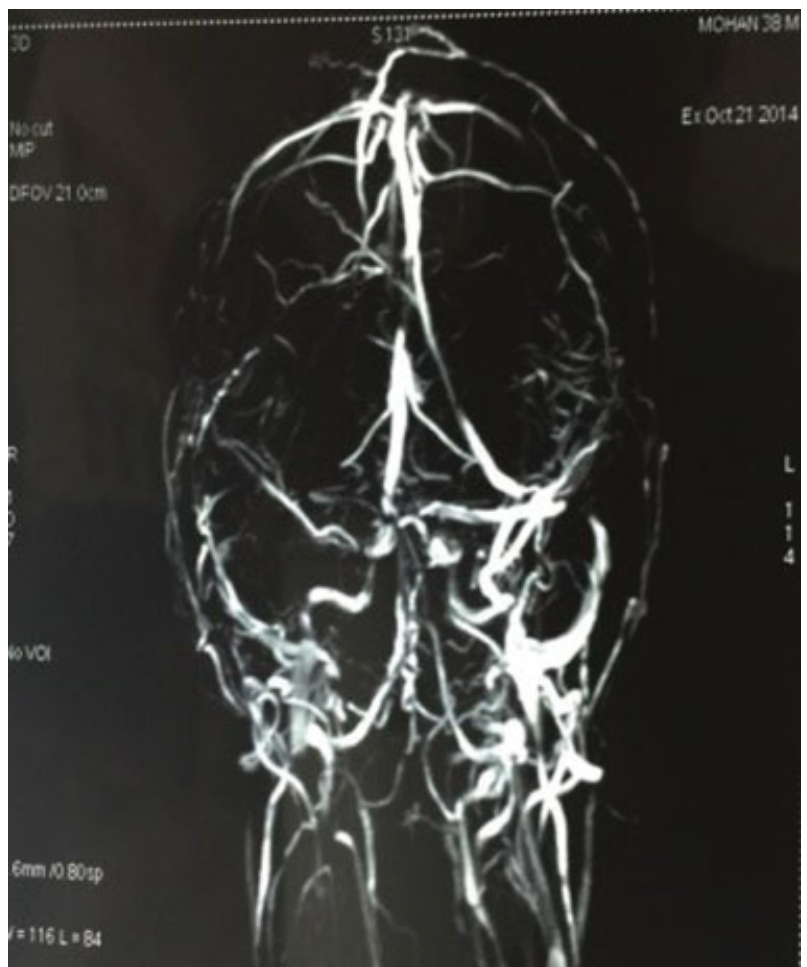

Fig. 7 Magnetic resonance Venogram. 


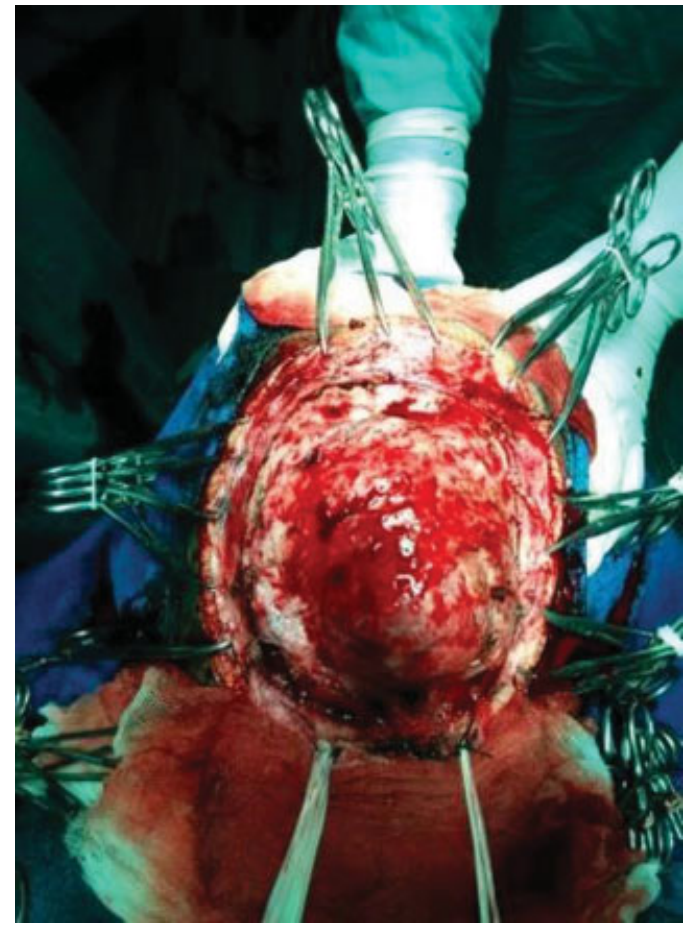

Fig. 8 Intraoperative photo of the tumor, prior to excision.

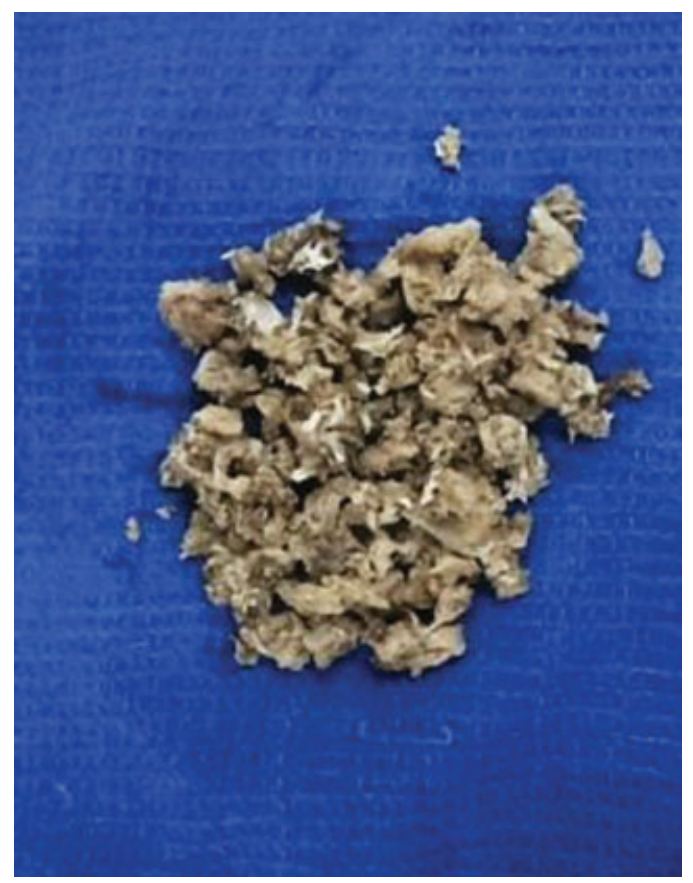

Fig. 10 Photo of excised bone infiltrated with tumor.

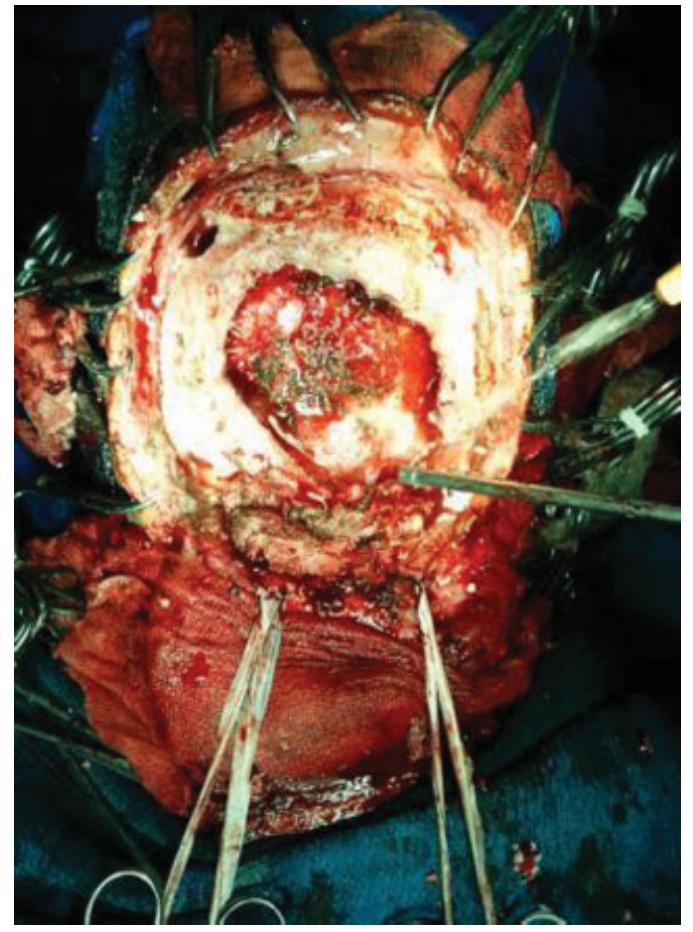

Fig. 9 Intraoperative photo of the tumor, post excision.

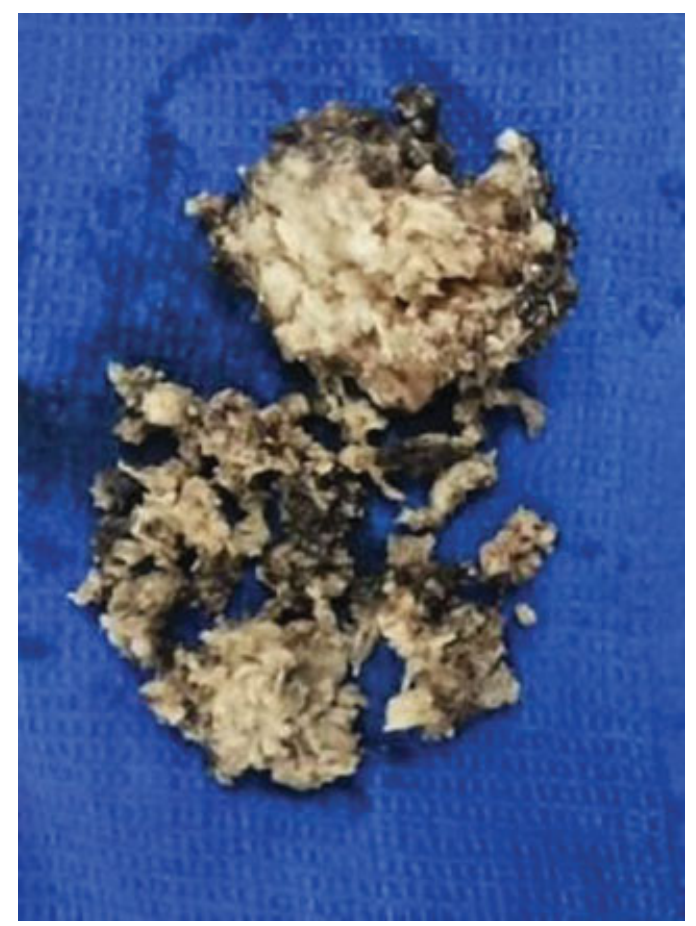

Fig. 11 Photo of excised tumor mass. 


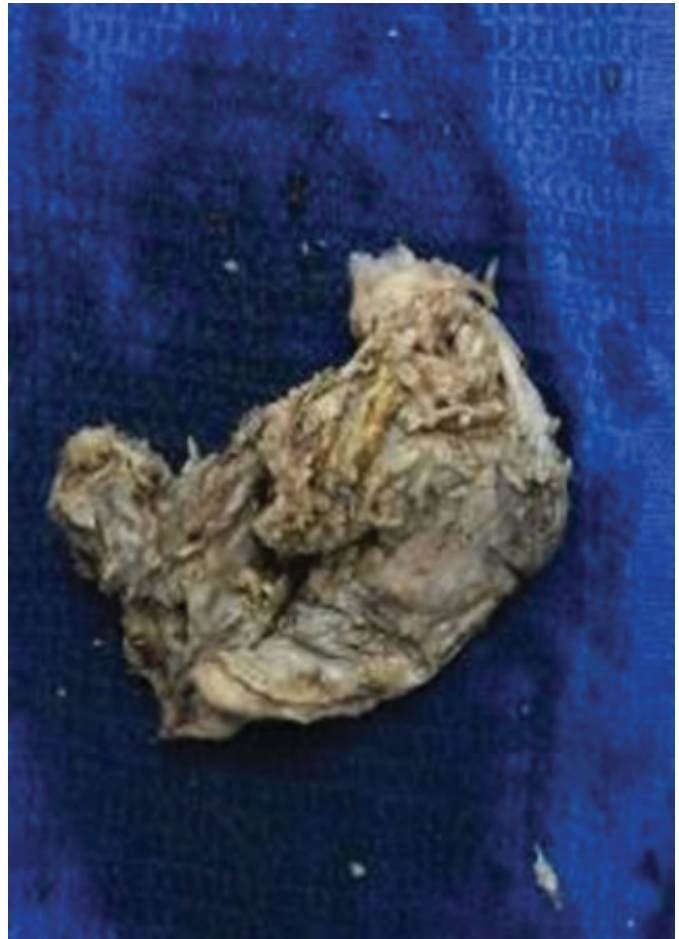

Fig. 12 Picture of tumor infiltrated suboccipital muscles.

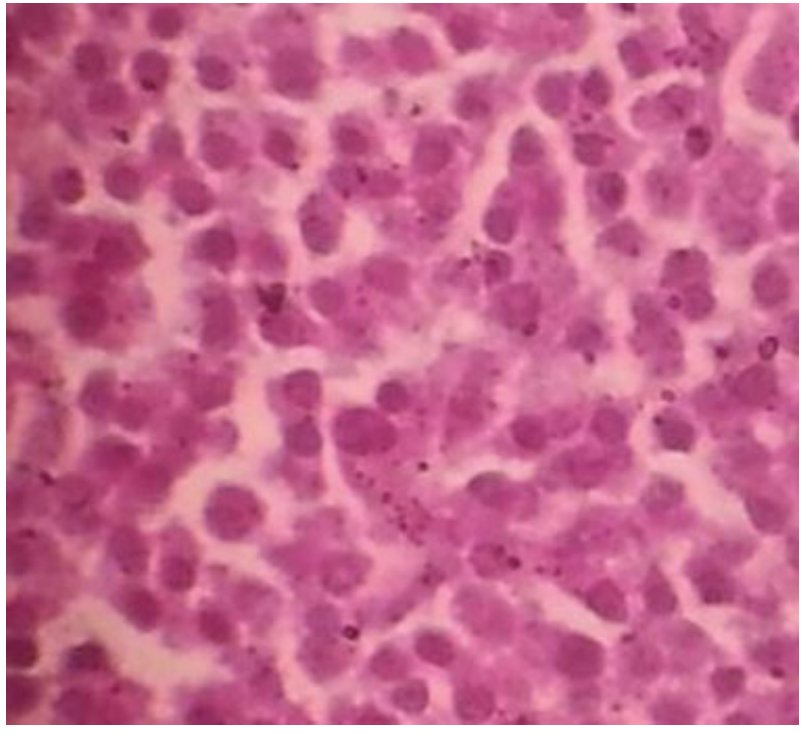

Fig. 14 Microscopic view of the plasma cells in the excised specimen.

\section{Histopathology}

Histopathology showed densely cellular infiltrate of tumor cells invading bony trabeculae. The tumor cells were plasmacytoid in appearance. The cells had large round eccentric hyperchromatic nuclei and were also seen with double nuclei in eosinophilic cytoplasm (-Fig. 14). The investigation

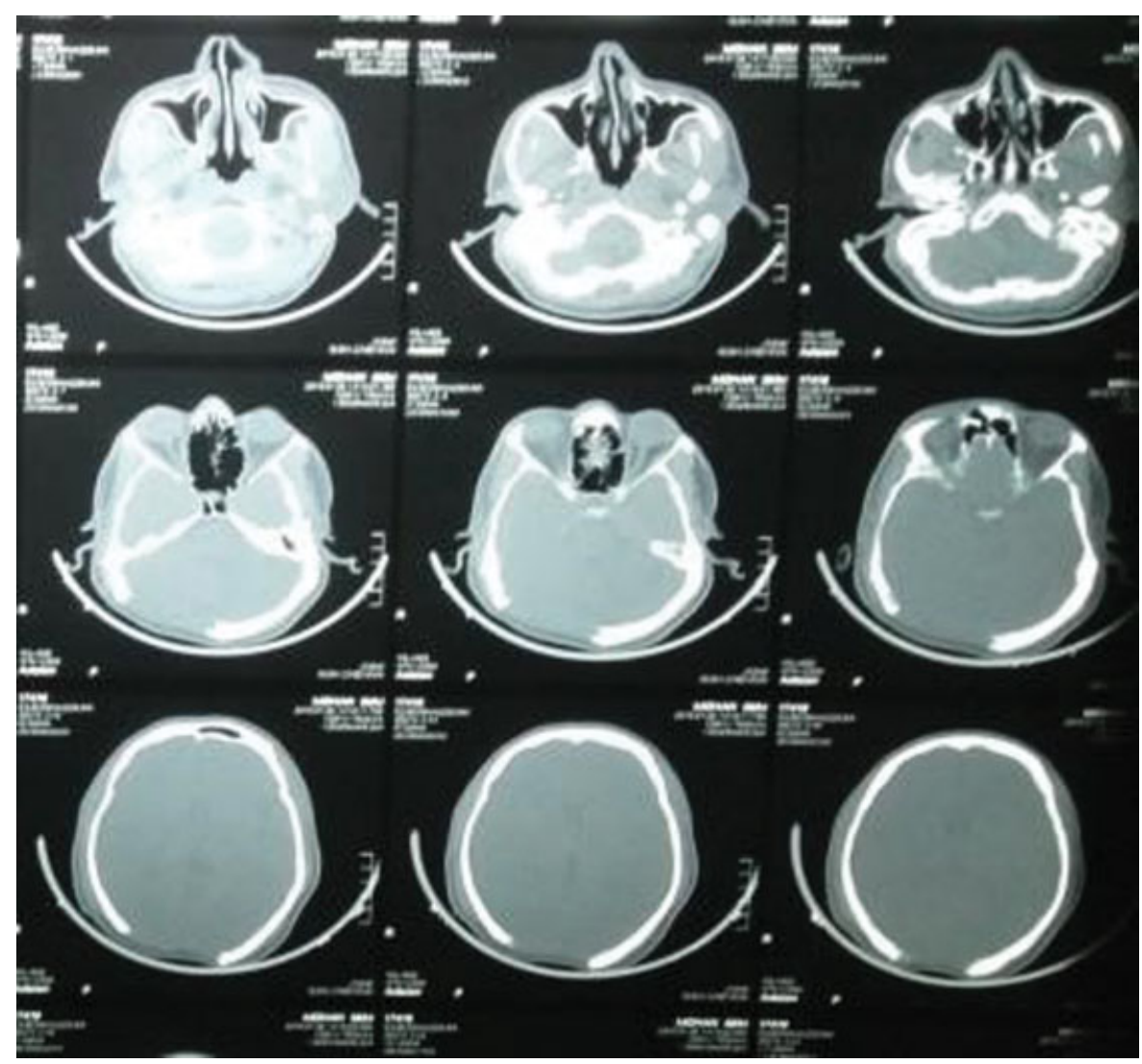

Fig. 13 Postoperative computed tomography scan of the brain. 


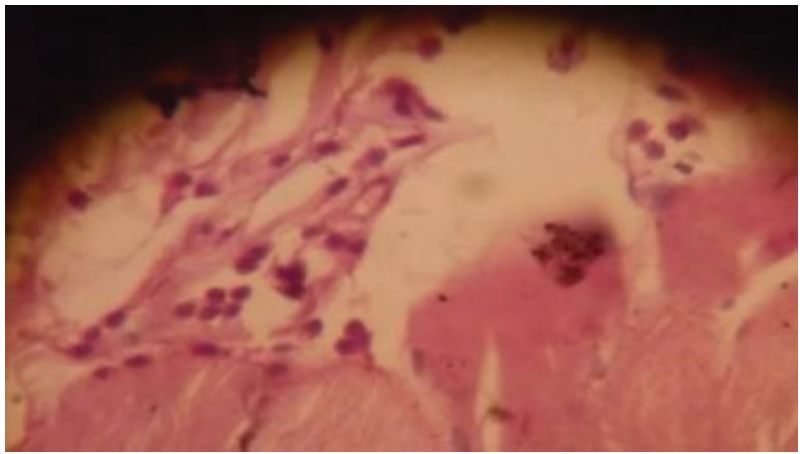

Fig. 15 Microscopic view of the plasma cells in the excised suboccipital muscles.

demonstrated the presence of suboccipital muscle infiltration with plasma cell (-Fig. 15).

\section{Immunohistochemistry}

CD-138 was positive (specific for plasma cell neoplasm) (-Fig. 16).

\section{Other Investigations}

Peripheral smear was negative for plasma cells. Bone marrow biopsy was negative for plasma cells. Urine Bence Jones protein was also negative. Serum M protein was reported

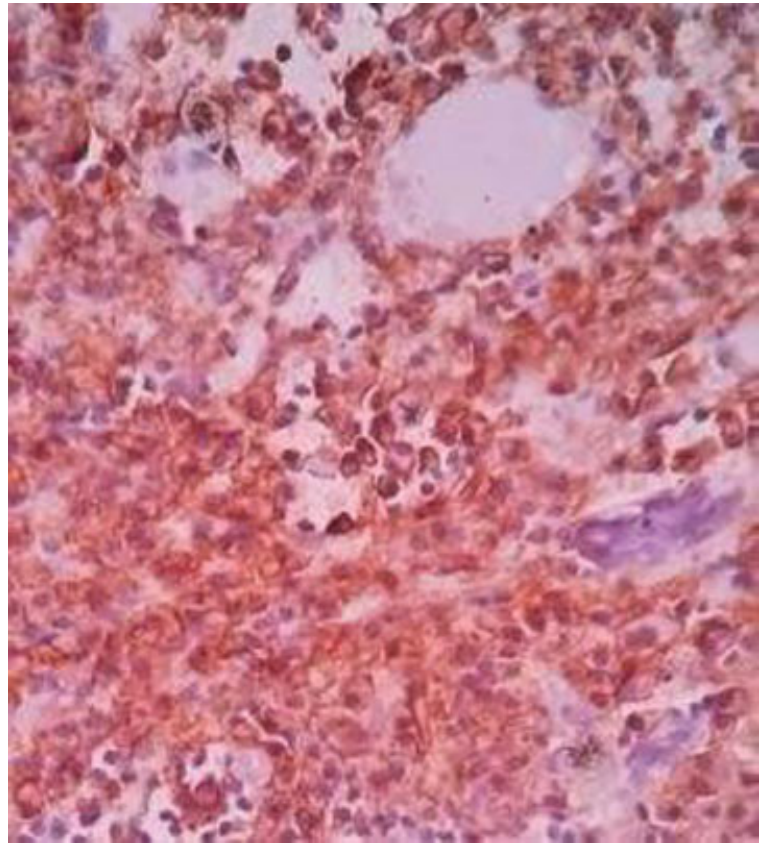

Fig. 16 Immuno histo chemistry slide with cells staining positively for CD-138 marker.

to be negative. The abdominal sonogram was also normal. Total Skeletal survey of long bones and pelvis were normal (-Fig. 17).

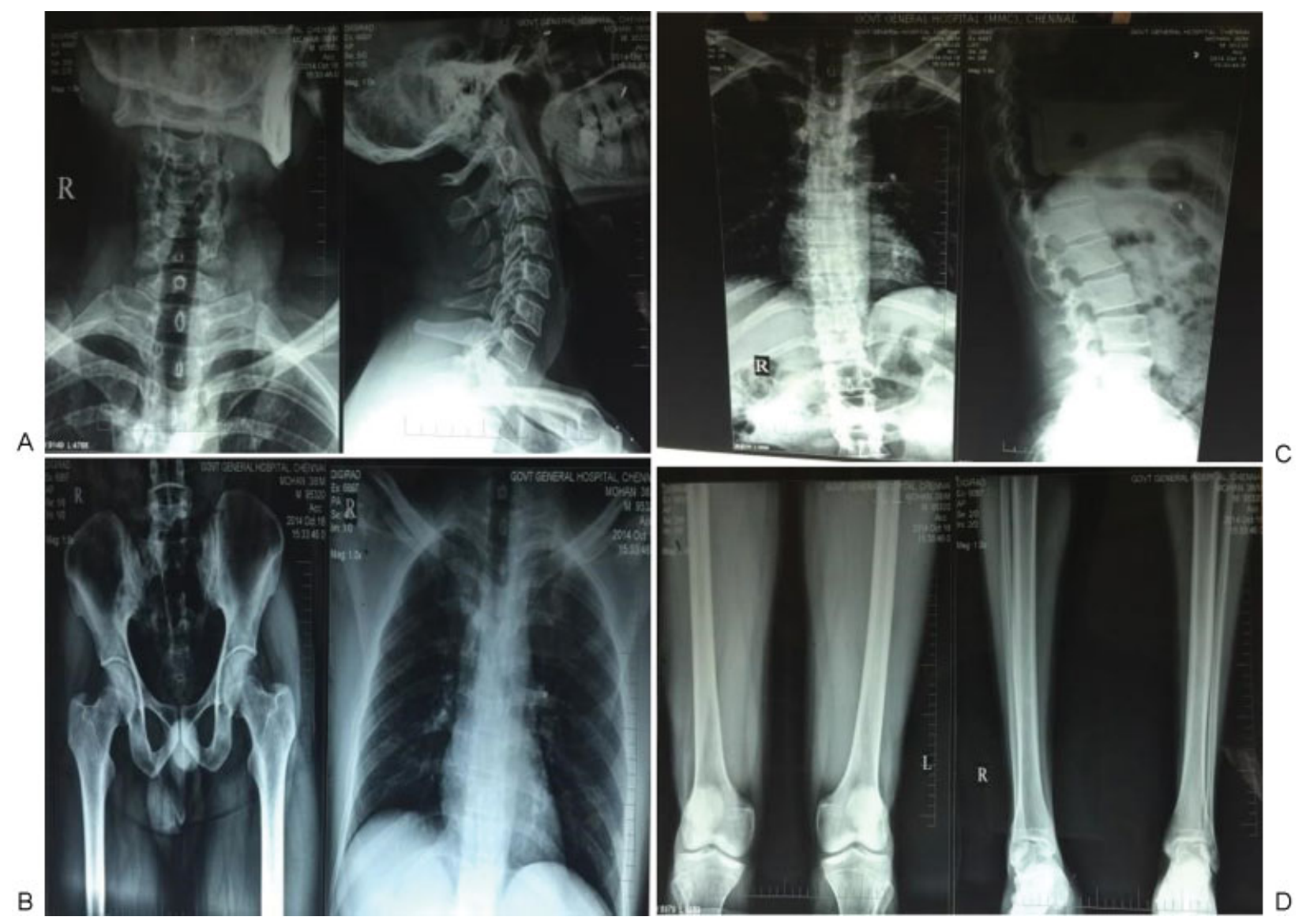

Fig. 17 Radiological skeletal survey with X-rays. 


\section{Treatment and Follow-up}

The patient has undergone radiotherapy and goes to followup once every three months. Routine examination of the patient's Bence Jones protein and serum $\mathrm{M}$ protein are negative to date.

\section{References}

1 Fanning SR, Hussein MA. Extramedullary Plasmacytoma. Medscape. Accessed on Dec 01, 2015. Available at: emedicine.medscape.com/article/207233-overview

2 Nguyen ML, Lieberman G. Osteolytic skull lesions. Beth Israel Deaconess Medical Centre. Acceseed on Sep 17, 2015. Available at: http://eradiology.bidmc.harvard.edu/LearningLab/musculo/ Nguyen2.pdf
3 Surov A, Tcherkes A, Meier F. Intramuscular plasmacytoma. Skeletal Radiol 2014;43(11):1561-1565

4 Ruiz Santiago F, Tello Moreno M, Martín Castro A, Guzmán Alvarez L, Navarrete González P. Soft tissue extramedullary plasmacytoma. Case Rep Med 2010;2010:307902

5 Thoumazet F, Donnio A, Ayeboua L, Brebion A, Diedhou A, Merle H. Orbital and muscle involvement in multiple myeloma. Can J Ophthalmol 2006;41(6):733-736

6 Rahmah N, Brotoarianto H, Andor E, Kusnarto G, Muttaqin Z, Hongo K. Dural plasmacytoma mimicking meningioma in a young patient with multiple myeloma. Biomed Imaging Interv J 2009;5(2):e5

7 Rajkumar SV. Diagnosis and management of solitary extramedullary plasmacytoma. Accessed on Dec 01,2015. Available at: www. uptodate.com/contents/diagnosis-and-management-of-solitaryextramedullary-plasmacytoma

8 Okamoto K, Ito J, Furusawa T, et al. Solitary plasmacytomas of the occipital bone: a report of two cases. Eur Radiol 1997;7(4): 503-506 